\title{
Epidermal Growth Factor and Postnatal Development of Intestinal Transport and Membrane Structure
}

\author{
K. OPLETA-MADSEN, J. B. MEDDINGS, AND D. G. GALL \\ Intestinal Disease Research Unit, Health Sciences Centre, University of Calgary, \\ Calgary, Alberta, T2N $2 N 1$ Canada
}

\begin{abstract}
The effects of epidermal growth factor (EGF) on postnatal development of intestinal transport and the physical composition of the microvillus membrane were examined. New Zealand White rabbits received EGF (40 $\mu \mathrm{g} / \mathrm{kg} / \mathrm{d}$ ) from $\mathrm{d} 3$ of life to $\mathrm{d} 17$ either intraperitoneally or orogastrically. Intestinal $\mathrm{H}_{2} \mathrm{O}, \mathrm{Na}^{+}$, and glucose absorption expressed per $\mathrm{cm}$ of intestine were significantly increased in animals receiving EGF by either route. When EGF was given by the orogastric route, nutrient absorption rates normalized to mucosal DNA were not elevated; thus, increased absorption induced by orogastric EGF appeared to be secondary to mucosal hyperplasia. In contrast, systemic EGF up-regulated cellular nutrient transport. To evaluate at which membrane level these changes occurred, brush border membrane vesicles were isolated from both the jejunum and ileum of control and EGF-treated animals. Rates of $\mathrm{Na}^{+}$-dependent glucose transport into the vesicles revealed that in the ileum systemic EGF up-regulated maximal rates of glucose transport by $54 \%$ without affecting the $\mathrm{Km}$. These observations were associated with alterations in the lipid composition and physical properties of the microvillus membrane. EGF-treated animals had significant reductions in membrane cholesterol content and altered ratios of phospholipid subclasses. The net result of these variations was that the microvillus membrane isolated from EGF-treated animals was significantly more fluid than membrane from controls. Thus, these results suggest that EGF modulates development of transport function during the postnatal period both by stimulating mucosal growth and by inducing specific transport processes. Furthermore, these changes are associated with alterations in the physical composition of the microvillus membrane. (Pediatr Res 30: 342-350, 1991)
\end{abstract}

\section{Abbreviations}

EGF, epidermal growth factor

BBMV, brush border membrane vesicles

HEPES, $N$-2-hydroxyethylpiperazine- $N^{\prime}$-2-ethanesulfonic acid

DPH, 1,6-diphenyl-1,3,5-hexatriene

SCN, thiocyanate

$\mathbf{J}_{\max }$, maximum transport rate

Received January 3, 1991; accepted May 16, 1991.

Correspondence and reprint requests: Dr. D. G. Gall, Department of Pediatrics. Health Science Centre, 3330 Hospital Drive N.W., Calgary, Alberta, T2N 4N Canada.

Supported by the Medical Research Council of Canada. J.B.M. is the recipient of an Alberta Heritage Foundation for Medical Research Clinical Investigatorship award
EGF is a small peptide of 53 amino acids (1), originally isolated from the submandibular gland of mice by Cohen (2). It has since been identified in Brunner's glands (3), saliva (4), urine (5), amniotic fluid (6), Paneth cells (7), and breast milk (8) and has been shown to have a variety of biologic effects. These include promotion of DNA synthesis (9-11) and transcription of RNA and subsequent protein synthesis (12).

Receptors for EGF are present along the length of the entire small intestine (13). Because of the presence of high concentrations of EGF in breast milk $(8,14)$, there has been speculation that this peptide might play a role in modulating postnatal development of the gastrointestinal tract. Although several studies have examined the effect of EGF on enzymatic function of the small intestine during the postnatal period $(15,16)$, the effect of EGF on nutrient and electrolyte transport function has only been examined with regards to $\mathrm{Ca}^{+}$transport (17). Additionally, the effects of systemic versus luminal EGF have not yet been clearly defined (16). Intestinal absorptive function continues to mature during the postnatal period. In general, the intestine of suckling animals is more permeable to $\mathrm{H}_{2} \mathrm{O}$ and electrolytes and, therefore, a significant proportion of transport occurs via diffusion (18). The suckling intestine has a limited capacity for active transport of electrolyte (19) and active absorption of bile salts appears only at weaning (20). Sodium-dependent glucose transport appears to be present at birth (21). The present study was undertaken to determine the effect of EGF on postnatal maturation of intestinal function.

\section{MATERIALS AND METHODS}

Animal model. Suckling New Zealand White rabbits received $40 \mu \mathrm{g} / \mathrm{kg} / \mathrm{d}$ EGF (Sigma Chemical Co., St. Louis, MO) either by daily intraperitoneal injection or via an orogastric feeding tube from d 3 of life to d 17. Littermate controls received $154 \mathrm{mM}$ saline in equivalent volumes by the appropriate route. Animals were weighed daily and studied at d 18-20.

Intestinal in vivo perfusion. On the day of study, animals were weighed and then anesthetized with halothane. In vivo absorption was measured by a single-pass perfusion technique as previously described (22). In separate experiments, either a 10 - to $15-\mathrm{cm}$ segment of jejunum, starting $10 \mathrm{~cm}$ distal to the ligament of Treitz, or ileum, ending at the meso appendix, was isolated and cannulated at each end. The segment was perfused at a constant rate of $0.1 \mathrm{~mL} / \mathrm{min}$. The perfusate contained $135 \mathrm{mM} \mathrm{Na}^{+}, 5$ $\mathrm{mM} \mathrm{K}+25 \mathrm{mM} \mathrm{HCO}-1,15 \mathrm{mM} \mathrm{Cl}^{-}, 5 \mathrm{~g} / \mathrm{L}$ of polyethylene glycol 4000 , and $10 \mu \mathrm{Ci} / \mathrm{L}$ of $\left[{ }^{14} \mathrm{C}\right]$ polyethylene glycol as the nonabsorbable marker, osmolality $310 \mathrm{mosmol} / \mathrm{L}$, and $\mathrm{pH} 7.4$ at $37^{\circ} \mathrm{C}$. In addition, the perfusate contained either $30 \mathrm{mM}$ glucose and $10 \mu \mathrm{Ci}\left[{ }^{3} \mathrm{H}\right.$ ]glucose; $10 \mathrm{mM}$ taurocholic acid and 10 $\mu \mathrm{Ci}\left[{ }^{3} \mathrm{H}\right]$ taurocholic acid; or an equivalent amount of mannitol. Body temperature was monitored by a rectal temperature probe and maintained by a heating mattress. After a 60 -min equilibra- 
tion period, studies were initiated with the mannitol-electrolyte solution. Three consecutive 20 -min samples were collected from the distal site. The perfusate was then changed to the glucose solution. After $40 \mathrm{~min}$ of equilibration, three more 20 -min samples were collected. In a separate group of animals, ileal absorption of bile salt was assessed by perfusing with the solution containing taurocholate during the second study period. Intraluminal hydrostatic pressure was constantly monitored and maintained below $3 \mathrm{~cm} \mathrm{H}_{2} \mathrm{O}$. After the second study period, the intestinal segment was removed and weighed, and its length measured. Mucosa was then scraped from the perfused segment, homogenized, and analyzed for DNA (23) and protein content (24). An adjacent segment of intestine was removed, scraped, and used for measurement of $\mathrm{Na}^{+} \mathrm{K}^{+}$ATPase activity (25). The collected samples were analyzed for $\mathrm{Na}^{+}$by flame spectrophotometry and for glucose, bile salt, and polyethylene glycol by scintillation spectrometry. Polyethylene glycol recovery ranged from $95-105 \%$ and did not differ between groups. Net fluxes of $\mathrm{H}_{2} \mathrm{O}, \mathrm{Na}^{+}$, glucose, and bile salts were calculated using standard formulas (26) and were expressed as $\mu \mathrm{L}$ or $\mathrm{nmol} / \mathrm{cm}$ or $\mathrm{mg}$ $\mathrm{DNA} / \mathrm{min}$.

Brush Border Membrane Studies. Vesicle preparation. BBMV were prepared from the proximal and distal one half of the small intestine of control and intraperitoneal EGF-treated animals by a magnesium chloride precipitation method (27). Purification was assessed by measuring sucrase sp act in the original homogenate and the final preparation (28). Basolateral membrane contamination was monitored by assaying $\mathrm{Na}^{+} \mathrm{K}^{+} \mathrm{ATP}$ Tse activity (25). Transport was calculated based upon the protein content of the vesicles as measured by the method of Lowry (24).

Transport measurements. Glucose uptake studies were carried

A

JEJUNUM

ILEUM

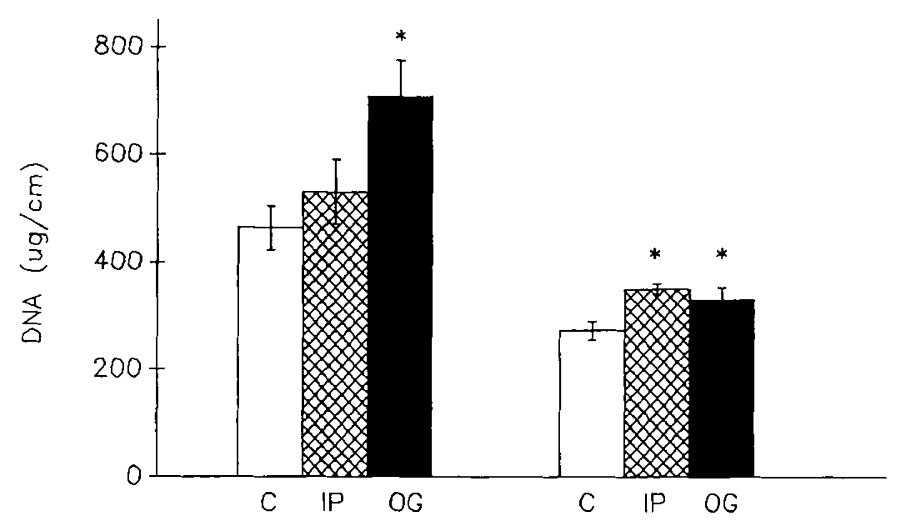

B

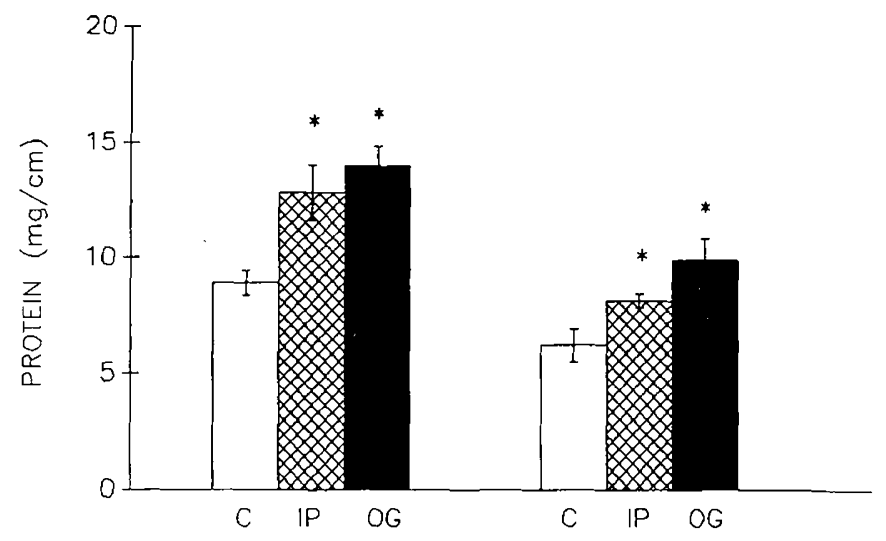

Fig. 1. DNA $(A)$ and protein $(B)$ content of mucosa from jejunal and ileal intestinal segments. $C$, control $(n=12) ; I P$, intraperitoneal $\operatorname{EGF}(n$ $=5) ; O G$, orogastric $\operatorname{EGF}(n=9)$. Values are means \pm SEM. ${ }^{*}, p<0.05$ compared with controls. out by a modification of Hopfer et al.'s (29) rapid filtration technique as previously described (30). Under the conditions used in these experiments, preliminary studies demonstrated that rates of glucose uptake were linear up to $10 \mathrm{~s}$, the overshoot peaked at $30 \mathrm{~s}$, and uptake reached equilibrium at $2 \mathrm{~min}$. Therefore, an incubation time of $5 \mathrm{~s}$ was used to estimate initial uptake rates of glucose at concentrations of glucose in the incubation medium ranging from $10 \mu \mathrm{M}$ to $8 \mathrm{mM}$. To start the reaction, $10 \mu \mathrm{L}$ of freshly prepared vesicles in a buffer containing $250 \mathrm{mM}$ mannitol, $10 \mathrm{mM}$ HEPES, and $10 \mathrm{mM}$ Tris at $\mathrm{pH} 7.5$ were added to $50 \mu \mathrm{L}$ of incubation buffer containing varying concentrations of $\left[{ }^{3} \mathrm{H}\right]$ glucose, $100 \mathrm{mM} \mathrm{NaSCN}, 50 \mathrm{mM}$ mannitol, and $20 \mathrm{mM}$ HEPES at $\mathrm{pH}$ 7.5. The diffusional component of uptake was measured by replacing $100 \mathrm{mM}$ cis-NaSCN with an equivalent concentration of KSCN. This component was subtracted from total uptake to give $\mathrm{Na}^{+}$-dependent D-glucose uptake. The reaction was stopped by the addition of $3 \mathrm{~mL}$ of ice-cold stop solution (20 mM HEPES, $100 \mathrm{mM} \mathrm{Na}^{+} \mathrm{Cl}^{-}$, and $150 \mathrm{mM}$ mannitol). The resultant mixture was filtered on a prewetted and chilled $0.45-\mu \mathrm{m}$ nitrocellulose filter (Millipore, Mississauga, Ontario, Canada) and washed with $9 \mathrm{~mL}$ of stop solution. Filters were then dissolved in scintillation vials by 10 $\mathrm{mL}$ of scintillation fluid and counted. Nonspecific binding of $\left[{ }^{3} \mathrm{H}\right]$ glucose to filters was measured by filtration of incubation medium, stop solution, and vesicles (without allowing mixing of medium and vesicles). All results were subsequently corrected for nonspecific binding. Volume of vesicles was routinely measured during each transport study by incubating vesicles with medium for $2 \mathrm{~h}$. The final volume of vesicles ranged from 0.6 to $1.1 \mu \mathrm{L} / \mathrm{mg}$ protein and did not differ between groups. Experiments were performed on at least four different freshly prepared vesicle preparations on different days. Uptake data are reported as nmol glucose absorbed $/ \mathrm{min} / \mathrm{mg}$ of vesicle protein.

Kinetic analysis. Initial rates of glucose uptake are presented as a function of the medium glucose concentration. To determine if the transport curves were better described by a one or two transporter model, the data were analyzed by the following equations, using weighted nonlinear regression techniques as previously described (31).

$$
\mathbf{J}=\frac{\mathrm{J}_{\mathrm{max}} \mathrm{C}}{\mathrm{Km}+\mathrm{C}}
$$

Equation 1 describes a single transport system where $J$ represents the rate of transport, $J_{\max }$ the maximum transport rate, $C$ the glucose concentration, and $\mathrm{Km}$ the concentration at which halfmaximal transport rates occur.

$$
J=\frac{J^{\prime}{ }_{\max } \mathrm{C}}{\mathrm{Km}^{1}+\mathrm{C}}+\frac{\mathrm{J}^{2}{ }_{\max } \mathrm{C}}{\mathrm{Km}^{2}+\mathrm{C}}
$$

Equation 2 describes a two transporter system containing two separate $\mathrm{J}_{\max }$ and $\mathrm{Km}$. To determine which model best described the transport system, the sums of squared residuals for each determination were compared using an $F$ test (31).

Membrane physical properties. Steady state fluorescence polarization studies were carried out using an SPF 500-C spectrofluorometer (SLM-Amino, Urbana, IL). The lipid soluble fluorophores DPH and $n$-(9-anthroyloxy) stearic acid (Molecular Probes, Junction City, OR), where $n$ took the values of 3, 6, 9, and 12, and 16-(9-anthroyloxy) palmitic acid were used to assess membrane physical properties. Vesicles were loaded with probe and measurements were performed as previously described (32). Data are reported as the steady state anisotropy parameter, $r_{s}$. Inasmuch as fluorescent lifetime cannot be directly obtained with steady-state techniques, total fluorescence was measured instead. Because total fluorescence is directly proportional to fluorescent lifetime, an absence of change in the former parameter was construed as evidence that the latter also had not changed. Finally, these techniques quantitate motional freedom of the probes utilized. The term membrane fluidity is used in its 

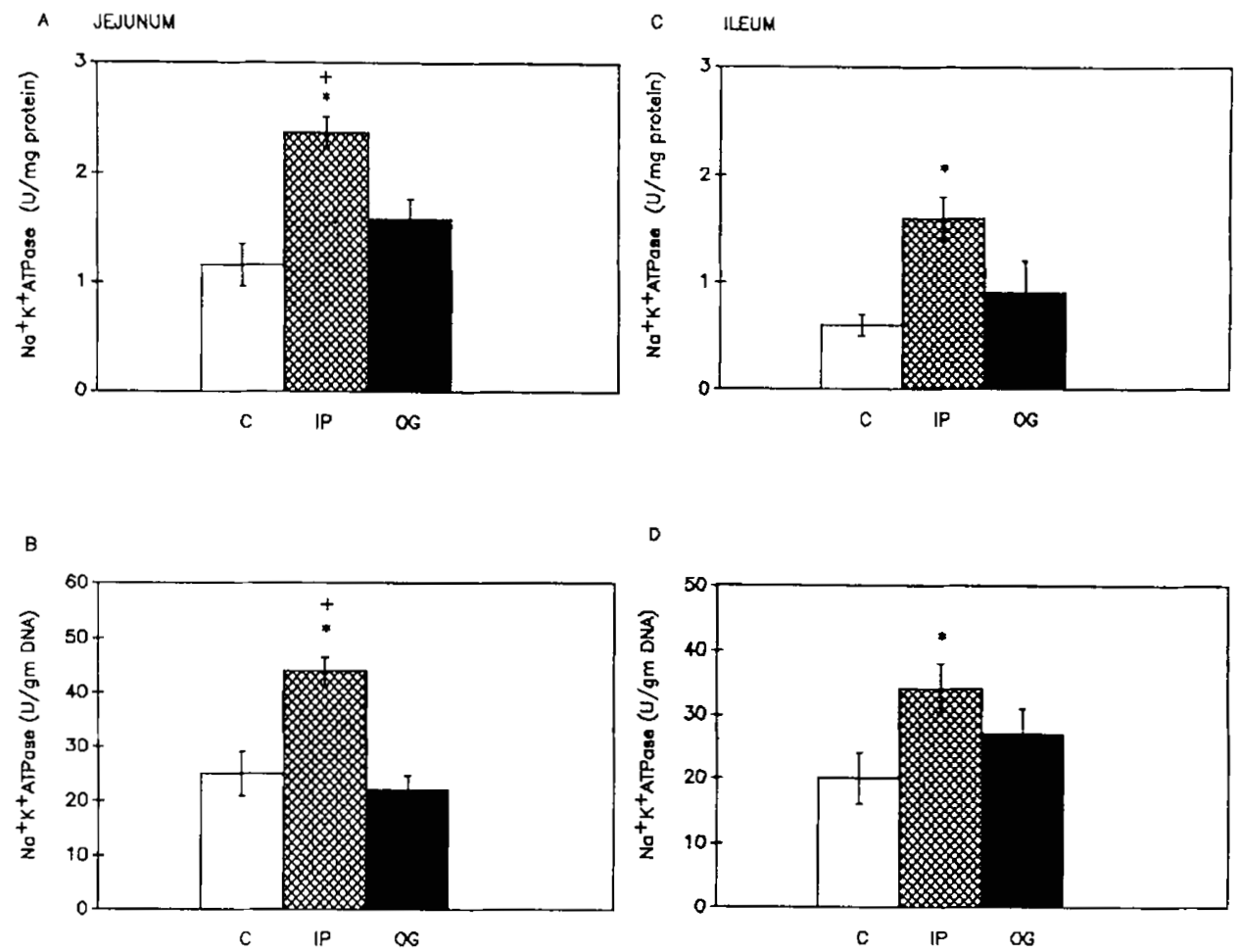

Fig. 2. Activity of $\mathrm{Na}^{+} \mathrm{K}^{+} \mathrm{ATPase}$ in the jejunum and ileum expressed as units/mg protein $(A$ and $C$ ) or units per mg DNA $(B$ and $D)$. C. control $(n=12) ; I P$, intraperitoneal EGF $(n=5) ; O G$, orogasiric EGF $(n=9)$. Values are means \pm SEM. ${ }^{*}, p<0.05$ compared with controls;,$+ p<0.05$ IP compared with OG.
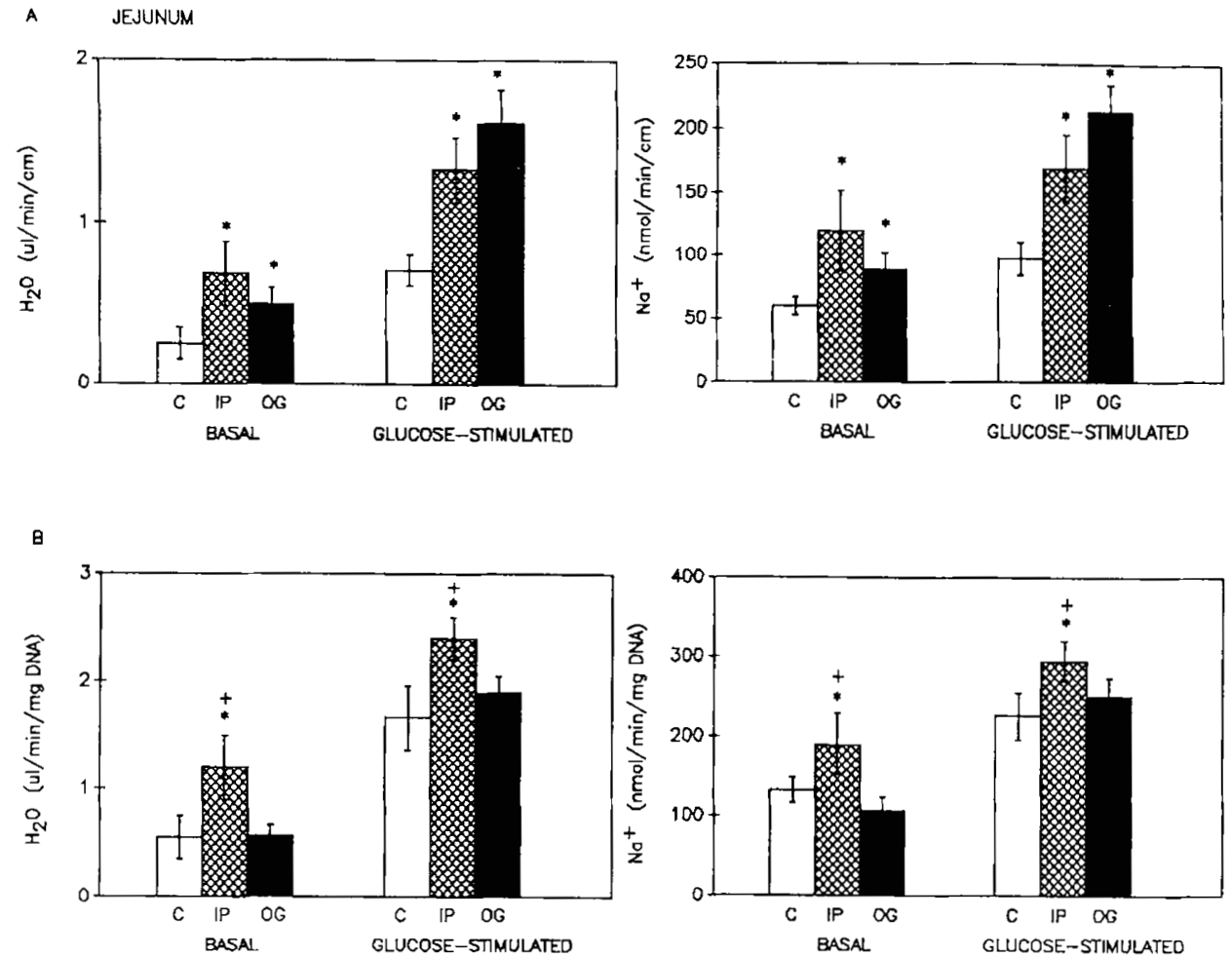

Fig. 3. In vivo net fluxes of $\mathrm{H}_{2} \mathrm{O}$ and $\mathrm{Na}^{+}$in jejunum under basal conditions (mannitol) and in the presence of glucosc. Fluxes were calculated as cither $\mathrm{nmol} / \mathrm{min} / \mathrm{cm}(A)$ or as $\mathrm{nmol} / \mathrm{min} / \mathrm{mg}$ DNA $(B)$. C , control $(n=12) ; I P$, intraperitonea! EGF $(n=5): O G$, orogastric EGF $(n=9)$. Each har represents the mean \pm SEM. ${ }^{*}, p<0.05$ compared with controls,,$+ p<0.05$ IP compared with OG.

broadest sense here. Increased motional freedom of the probe is referred to as increased membrane fluiditiy.

Membrane lipid composition. Membrane lipids were extracted by the method of Folch et al. (33). Total phospholipid content of the membrane extract was determined by the method of Ames and Dubin (34) and cholesterol content, by a cholesterol oxidase enzymatic method (Boehringer Mannheim, Dorval, Quebec, Canada). Aliquots of extracted lipid were plated on Whatman LK-5D TLC plates and developed as previously described (30). The resultant phospholipid species were identified by simulta- 


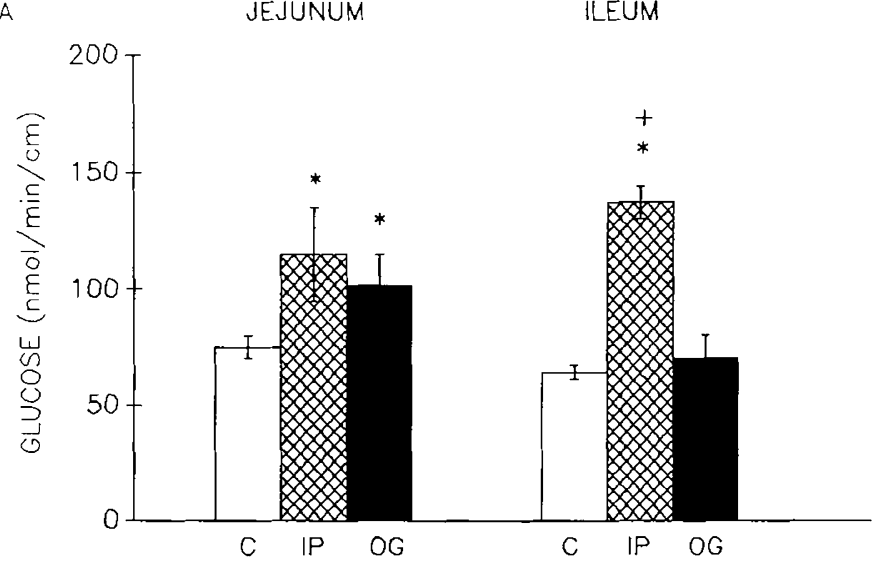

B

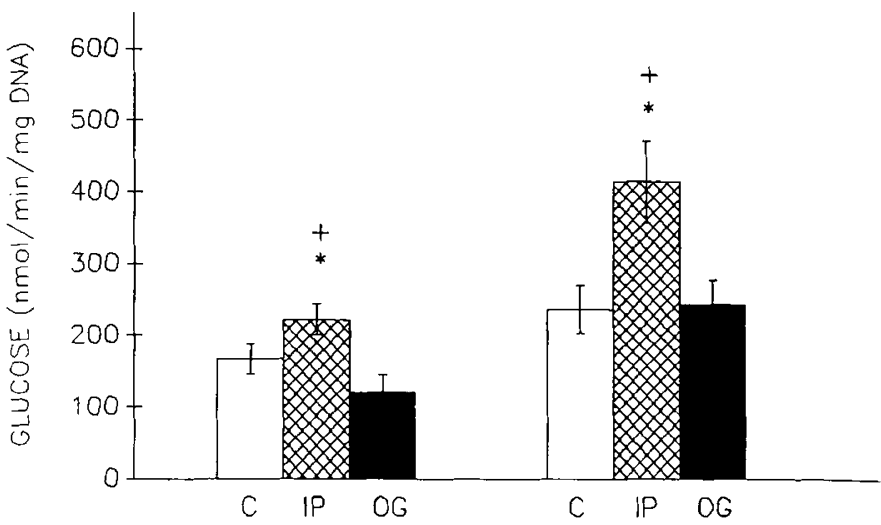

Fig. 4. In viro net absorption of glucose in jejunal and ileal intestinal segments. Absorption was calculated as either $\mathrm{nmol} / \mathrm{min} / \mathrm{cm}$ (A) or as $\mathrm{nmol} / \mathrm{min} / \mathrm{mg}$ DNA $(B)$. C. control $(n=12) ; I P$. intraperitoneal EGF $(n=5): O G$, orogastric EGF $(n=9)$. Each har represents the mcan \pm SEM. ${ }^{*}, p<0.05$ compared with controls:,$+ p<0.05$ IP compared with OG

neously running authentic standards (Supelco, Bellafonte, CA). Identified phospholipids were aspirated into reaction tubes after drying under nitrogen. Pentadecanoic acid was added as an internal standard and fatty acid methyl esters prepared by standard techniques (32). These were separated and quantitated using gas-lipid chromatography, also as previously described (30).

Statistical Analysis. Results are expressed as means \pm SEM. Analysis of variance was used to compare results between groups.

\section{RESULTS}

Final body weight was not affected by the administration of EGF. At 18-20 d of age, mean body weight of intraperitoneally $(291 \pm 13 \mathrm{~g})$ and orogastrically $(288 \pm 15 \mathrm{~g})$ treated animals did not differ from controls $(298 \pm 7 \mathrm{~g})$.

Mucosal DNA and Protein Content and $\mathrm{Na}^{+} \mathrm{K}^{+}$ATPase Activity. As we have previously shown (16), EGF had a trophic effect on the jejunal mucosa. Orogastric EGF caused a significant increase in jejunal mucosal DNA (Fig. $1 A$ ), whereas both intraperitoneal and orogastric EGF caused an increase in jejunal mucosal protein content (Fig. $1 B$ ). In the ileum, intraperitoneal and orogastric EGF caused significant increases in both mucosal DNA (Fig. $1 A$ ) and protein (Fig. $1 B$ ). Animals receiving systemic EGF demonstrated a significant increase in jejunal and ileal $\mathrm{Na}^{+} \mathrm{K}^{+} \mathrm{ATP}$ ase compared with controls when calculated either per g protein (Fig. $2 A$ and $C$ ) or mg DNA (Fig. $2 B$ and $D$ ).

In Vivo Perfision. Jejunum. In vivo perfusion of the jejunum demonstrated a significant increase in $\mathrm{H}_{2} \mathrm{O}$ and $\mathrm{Na}^{+}$absorption during the basal period in animals receiving orogastric $(n=9)$ or intraperitoneal ( $n=5)$ EGF compared with controls $(n=12)$ (Fig. $3 A$ ). The presence of $30 \mathrm{mM}$ glucose in the perfusate significantly $(p<0.01)$ stimulated $\mathrm{H}_{2} \mathrm{O}$ and $\mathrm{Na}^{+}$absorption in all groups (Fig. $3 A$ ). However, $\mathrm{H}_{2} \mathrm{O}$ and $\mathrm{Na}^{+}$absorption remained significantly greater in the EGF-treated animals. Net absorption of glucose was also increased in the EGF-treated animals compared with controls (Fig. 4A). Because increased nutrient absorption per $\mathrm{cm}$ length of intestine might be secondary to either an increase in mucosal mass or induction of cellular transport, absorption was also calculated based on mucosal DNA. The increase in $\mathrm{H}_{2} \mathrm{O}$ and $\mathrm{Na}^{+}$absorption induced by orogastric EGF disappeared when the data were normalized to mucosal DNA (Fig. $3 B$ ). A similar pattern was seen with glucose absorption (Fig. $4 B$ ). Increased absorption rates induced by orogastric EGF per $\mathrm{cm}$ of intestine are no longer apparent when expressed per cell (DNA). These findings suggest that the jejunal response to orogastric EGF is due to the observed mucosal hyperplasia and not to an increase in the rate of absorption per cell. In contrast, in animals receiving systemic EGF, absorption remained significantly elevated when normalized to mucosal DNA, indicating an induction of cellular transport (Figs. $3 B$ and $4 B$ ).

Ileum. Similar results were observed when an ileal loop was perfused. In the basal period, $\mathrm{H}_{2} \mathrm{O}$ absorption and $\mathrm{Na}^{+}$absorption were significantly increased with systemic EGF, and $\mathrm{Na}^{+}$ absorption was significantly increased with orogastric EGF when expressed per $\mathrm{cm}$ length of intestine (Fig. $5 \mathrm{~A}$ ). The addition of either glucose (intraperitoneally, $n=7$; orogastrically, $n=9$ ) or taurocholate (intraperitoneally, $n=6$; orogastrically, $n=5$ ) to the perfusate caused a significant $(p<0.05)$ increase in $\mathrm{H}_{2} \mathrm{O}$ and $\mathrm{Na}^{+}$absorption in both EGF groups, whereas only taurocholate $(n=14)$ increased $(p<0.05)$ absorption in control animals. Glucose $(n=14)$ had no effect. In the presence of glucose and taurocholate, absorption remained elevated in the EGF groups compared with control values. When the data were expressed per mg mucosal DNA (Fig. $5 \mathrm{~B}$ ), $\mathrm{H}_{2} \mathrm{O}$ and $\mathrm{Na}^{+}$absorption remained significantly elevated in the systemically treated animals. In the orogastric group, absorption was only increased in the presence of glucose. Net absorption was only increased in the presence of glucose. Net absorption of glucose (Fig. 4) and taurocholate (Fig. 6) was also enhanced by systemic EGF, and this effect was apparent regardless of whether the data were normalized per $\mathrm{cm}$ length or per mucosal DNA content.

Brush Border Membrane Studies. Purification and validation. To determine if intraperitoneal EGF produced its effect at the level of the microvillus membrane, this subcellular fraction was isolated from both control and systemically treated animals. The purification of membrane vesicles based upon enrichment of sucrase activity was similar in controls and EGF-treated animals (Table 1). There was no detectable $\mathrm{Na}^{+} \mathrm{K}^{+}$ATPase activity in microvillus membrane in either group, indicating negligible contamination by basolateral membranes.

To determine if the uptake of D-glucose was into an osmotically sensitive intravesicular space rather than binding to membrane surfaces, BBMV from both controls and EGF-treated animals were incubated in medium of increasing osmolarity to decrease intravesicular space. The amount of glucose taken up by vesicles prepared from both groups was linearly related to the reciprocal of medium osmolarity and had a $y$-intercept not significantly different from zero (data not shown). These data indicate that glucose uptake was into an osmotically sensitive space and make it unlikely that adsorption contributed significantly.

Kinetic results. Figure 7 illustrates $\mathrm{Na}^{+}$-dependent rates of glucose uptake into BBMV from proximal (panel $A$ ) and distal (panel $B$ ) intestine. These data have been corrected for rates of transport observed in the absence of an $\mathrm{Na}^{+}$gradient. Systemic EGF had little effect on the kinetics of $\mathrm{Na}^{+}$-dependent glucose transport in BBMV from the proximal intestine. However, in BBMV from distal intestine, systemic EGF produced a significant increase in maximal rates of glucose transport. 

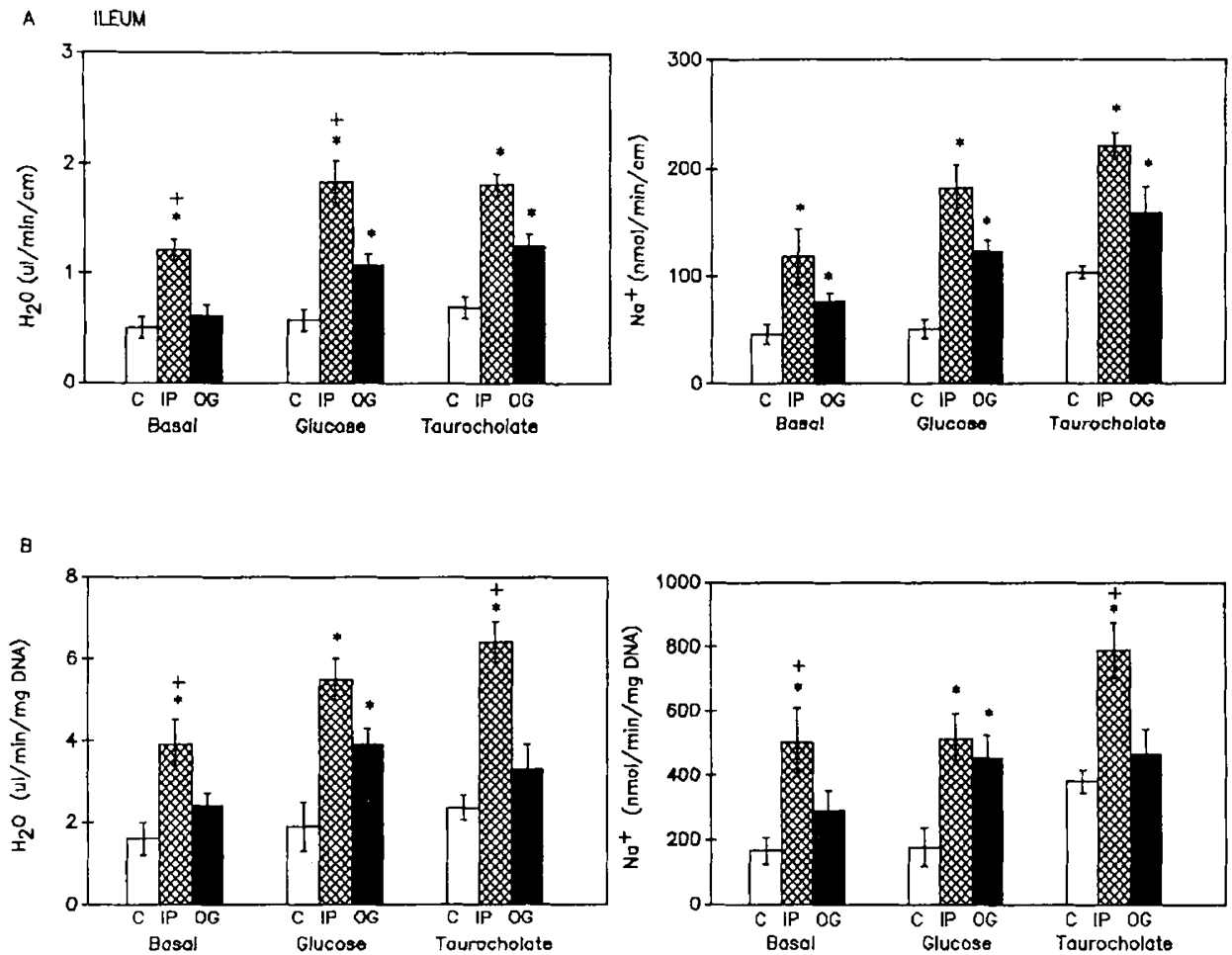

Fig. 5. In vivo net fluxes of $\mathrm{H}_{2} \mathrm{O}$ and $\mathrm{Na}^{+}$in ileum under basal conditions (mannitol) and in the presence of either glucose or bile salts. Fluxes were calculated as either $n \mathrm{~mol} / \mathrm{min} / \mathrm{cm}(A)$ or as $\mathrm{nmol} / \mathrm{min} / \mathrm{mg}$ DNA $(B)$. C. control $(n=14) ; I P$, intraperitoneal EGF $(n=7) ; O G$, orogastric EGF $(n=9)$. Each har represents the mean \pm SEM. ${ }^{*}, p<0.05$ compared with controls;,$+ p<0.05$ IP compared with OG.

The kinetic parameters that describe these curves were defined by nonlinear regression techniques as outlined in Materials and Methods. Initially, the data were fit to a model that incorporated either one or two transporters. No statistically significant difference was observed in the "goodness of fit" parameter between models ( $F$ test). Thus, the data were fit to an equation involving a single transporting site. The kinetic parameters observed in BBMV from proximal intestine in EGF-treated animals $\left(\mathrm{J}_{\max }\right.$, $2.2 \pm 0.5 \mathrm{nmol} / \mathrm{min} / \mathrm{mg}$ protein; $\mathrm{Km}, 489 \pm 120 \mu \mathrm{M}$ ) were not different from those observed in control animals $\left(\mathrm{J}_{\max }, 3.1 \pm 0.4\right.$ $\mathrm{nmol} / \mathrm{min} / \mathrm{mg}$ protein; $\mathrm{Km}, 279 \pm 26 \mu \mathrm{M})$. However, in BBMV isolated from the distal intestine of EGF-treated animals, a significant $(p<0.05)$ increase in maximal glucose transport rates, $\mathrm{J}_{\max }$, was observed $(4.2 \pm 0.2$ versus $2.7 \pm 0.2 \mathrm{nmol} / \mathrm{min} / \mathrm{mg}$ protein). Values for the $\mathrm{Km}$ did not differ ( $216 \pm 21$ versus 334 $\pm 55 \mu \mathrm{M})$. The passive component of transport measured in the absence of an $\mathrm{Na}^{+}$gradient was not different between control and EGF-treated animals (at $4 \mathrm{mM}$ glucose: $1.7 \pm 0.8$ versus 2.7 $\pm 0.8 \mathrm{nmol} / \mathrm{min} / \mathrm{mg}$ protein).

Membrane physical properties. Because membrane physical properties may affect the kinetics of $\mathrm{Na}^{+}$-dependent glucose transport (35), physical properties and lipid composition of BBMV from controls and animals receiving systemic EGF were quantitated. Membrane physical properties were estimated by determining both the static and dynamic components of membrane fluidity. The former was assessed using the probe DPH, and the latter was evaluated at several depths within the bilayer using a series of $n$-(9-anthroyloxy) fatty acids, where $n$ took the value of $3,6,9,12$, and 16 . Thus, 3-(9 anthroyloxy) stearic acid probes events taking place near the surface of the bilayer, whereas 16-(9-anthroyloxy) palmitic acid localizes close to the core of the membrane.

Table 2 summarizes the data regarding the static component of membrane fluidity. The observed steady-state anisotropy parameters for DPH were significantly lower in BBMV obtained from EGF-treated animals. Although fluorescent lifetime cannot be directly measured with steady-state techniques, it can be indirectly assessed by measuring the total fluorescence of the sample. Because total fluorescence for a constant amount of membrane and probe did not differ between groups, we infer that the difference in anisotropy was unlikely to be secondary to changes in fluorescent lifetime. The observed differences in anisotropy parameter translate into a significant reduction in membrane order associated with the administration of EGF.

These differences in membrane physical properties induced by EGF were not limited to the static component of membrane fluidity. As illustrated in Figure 8, the dynamic component of membrane fluidity was also altered and involved almost all depths of the bilayer examined by these probes. In all cases, EGF treatment was associated with a reduction in the anisotropy parameter of the probe, a change that suggests increased motional freedom for the fluorescent group. Once again, no significant differences were observed in total fluorescence (data not shown), implying that these differences were unlikely to be secondary to differences in fluorescent lifetime.

Table 3 summarizes the lipid composition of the BBMV. Microvillus membrane isolated from EGF-treated animal was not only more fluid, but also had a significantly lower cholesterol content than membrane isolated from control animals. This alteration was primarily responsible for a significant reduction in the cholesterol:phospholipid ratio observed in these membranes. Inasmuch as this parameter is one of the major determinants of membrane physical properties, these alterations may explain many of the observed alterations in membrane fluidity. However, it was not the only factor involved. In BBMV from the distal intestine, EGF administration also led to alterations in the relative abundance of phospholipid subclasses. A significant decrease in the phosphatidylethanolamine to phosphatidylcholine and sphingomyelin to phosphatidylcholine ratios were observed. These changes would also contribute to the observed increase in membrane fluidity.

\section{DISCUSSION}

Our results suggest that during the postnatal period, EGF may modulate the transport capacity of the small intestine and alter 
A
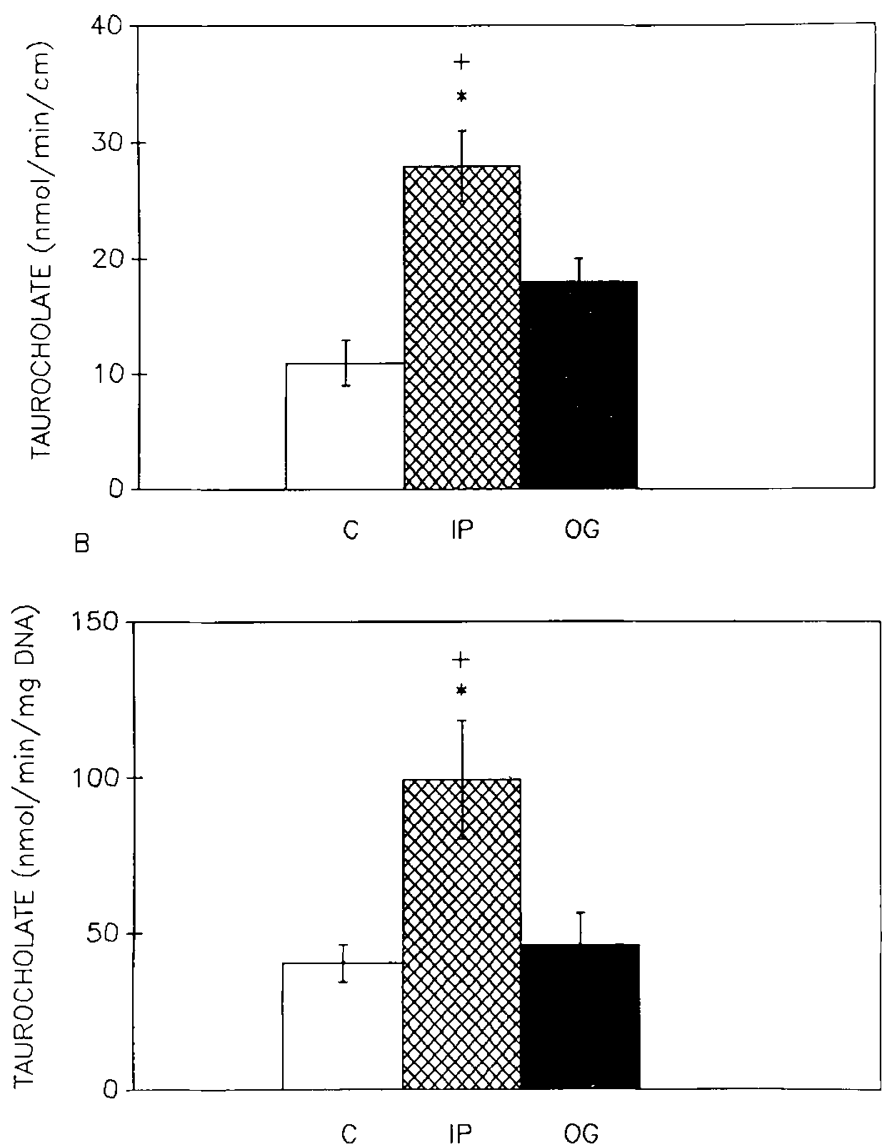

Fig. 6. In rive net absorption of taurocholate in the ileal intestinal segment. Absorption was calculated as either $\mathrm{nmol} / \mathrm{min} / \mathrm{cm}(A)$ or as $\mathrm{nmol} / \mathrm{min} / \mathrm{mg}$ DNA $(B)$. C, control $(n=14)$; $1 \mathrm{P}$, intraperitoneal EGF $(n=6): O(j$, orogastric EGF $(n=5)$. Each bar represents the mean \pm SEM. *. $p<0.05$ compared with controls,,$+ p<0.05$ IP compared with OG

brush border membrane composition and function in suckling rabbits.

The effects of EGF on cellular proliferation and maturation appear to be dependent upon both the time of exposure (17) and the route of administration $(36,16,37)$. In this study, the administration of EGF via an oral route had a trophic effect that was greatest in the jejunum and decreased toward the distal ileum. Systemically administered EGF had a trophic effect in both jejunum and ileum.

The presence of a normal proximal-distal gradient in EGF absorption in suckling animals (38) would result in exposure of the jejunum to much higher levels of EGF compared with the ileum in experimental animals receiving oral supplementation of EGF. In contrast, in animals receiving systemic EGF, both proximal and distal regions of the intestine would be exposed to similar EGF levels at the basolateral membrane surface. Inas- much as intestinal epithelial cells are extremely sensitive to EGF concentration (15), the differing effects of oral versus systemic administration may be partially related to the actual concentration reaching the cells. In addition, the presence of receptors for EGF on the brush border of nondividing villus tip cells (39), together with the observation that receptors are also located on the basolateral membrane (40), leads to the speculation of a mechanism for EGF absorption and action similar to that proposed for polyamines (41). In this model, villus cells would take up EGF and release the peptide into the interstitium where it would be carried via the local circulation to basolateral membranes of crypt cells. Evidence to support this idea comes from the studies by Ulshen et al. (42) in which the intraluminal infusion of EGF into the ileum resulted in an increase in DNA synthesis in the jejunum.

The small intestine undergoes several developmental changes that affect transport capacity and function during the postnatal period. The immature intestine is more permeable to water and electrolytes (19), possibly due to a more disordered structure of the microvillus membrane $(32,43)$. Maturation of the small intestine involves decreases in both brush border (43) and basolateral membrane (44) fluidity associated with increases in the cholesterol/phospholipid molar ratio (32). In the present study, EGF administration resulted in an increase in the fluidity of microvillus membrane. Membrane fluiditiy is controlled by a variety of regulatory mechanisms involving membrane lipid composition. Multiple factors seemed to be responsible for this alteration. First and foremost. EGF led to a reduction in the cholesterol:phospholipid ratio, a prime determinant of membrane physical properties. Secondly, in the ileum EGF increased the relative concentration of phosphatidylcholine. This resulted in reduction of both the phosphatidylethanolamine:phosphatidylcholine and sphingomyelin:phosphatidylcholine ratios. Both would be expected to increase the observed fluidity of the microvillus membrane. The underlying mechanisms of these alterations can only be speculated upon given our data. However, stimulation of transmethylation reactions converting phosphatidylethanolamine to phosphatidylcholine (45) is possible. Furthermore, luminal EGF has been shown to decrease the microclimate $\mathrm{pH}$ along the apical membrane surface in rat jejunum (46). Similar alterations have been demonstrated to result in increased fluidity due to a displacement of $\mathrm{Ca}^{+}$ions (47).

The effects of altering phospholipid composition on membrane function are not well understood. There is no simple relationship that exists between any specific phospholipid and transport function. Alterations in membrane fluidity have been shown to affect glucose transport $(30,35), \mathrm{Na}^{+} \mathrm{K}^{+}$-ATPase activity (48), and sodium uptake and water permeability (49). In the intestine, a proximal distal gradient exists in membrane lipid composition and fluidity, with the jejunum being more fluid than the ileum (50). The jejunum is also more permeable than the ileum, because of both decreased paracellular resistance and less rigid brush border membrane. The apparent fluidization of membranes by EGF administration resulted in an ileal brush border membrane that was similar in degree of fluidity to normal control jejunal membranes. This suggests that the presence of EGF in the gut may be instrumental in the maintenance of the normal proximal distal gradient in fluidity.

Table 1. Enzymatic characterization of microvillus membrane preparations*

\begin{tabular}{|c|c|c|c|c|c|c|}
\hline \multirow[b]{2}{*}{ Group } & \multirow[b]{2}{*}{ Treatment } & \multicolumn{2}{|c|}{ Sucrase activity (U/g protein) } & \multirow[b]{2}{*}{$\begin{array}{l}\text { Enrichment } \\
\text { factor (fold) }\end{array}$} & \multicolumn{2}{|c|}{$\mathrm{Na}^{+} \mathrm{K}^{+} \mathrm{ATPase}(\mathrm{U} / \mathrm{mg}$ protcin) } \\
\hline & & Homogenate & $\begin{array}{l}\text { Microvillus } \\
\text { membrane }\end{array}$ & & Homogenate & $\begin{array}{l}\text { Microvillus } \\
\text { membrane }\end{array}$ \\
\hline \multirow[t]{2}{*}{ Jejunum } & Control & $4.0 \pm 2.0$ & $66.1 \pm 33.0$ & 16.5 & $1.0 \pm 0.2$ & ND \\
\hline & EGF i.p. & $6.0 \pm 2.0$ & $114.0 \pm 47.0$ & 19.0 & $1.9 \pm 0.4$ & ND \\
\hline \multirow[t]{2}{*}{ Ileum } & Control & $1.1 \pm 0.6$ & $25.1 \pm 13.0$ & 23.0 & $0.5 \pm 0.3$ & ND \\
\hline & EGF i.p. & $2.5 \pm 1.0$ & $44.7 \pm 19.0$ & 18.0 & $1.4 \pm 0.4$ & ND \\
\hline
\end{tabular}

* Values are means \pm SEM; ND. not detectable: i.p., intraperitoneally. 
A PROXIMAL INTESTINE

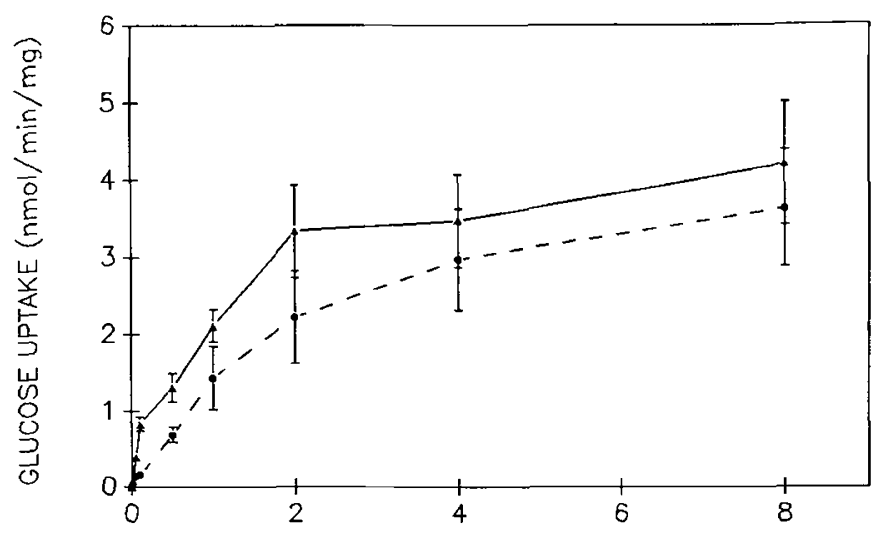

B DISTAL INTESTINE

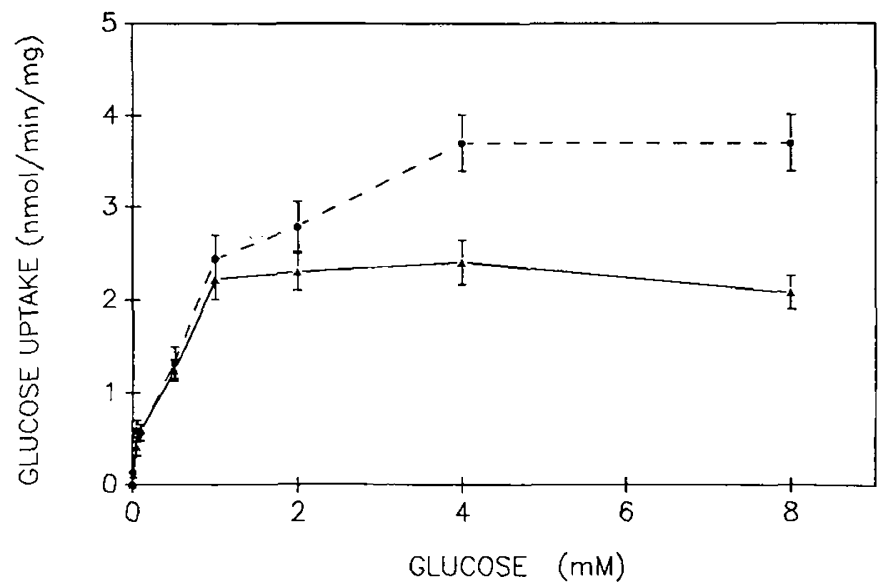

Fig. 7. Initial rates of D-glucose transport as a function of D-glucose concentrations in the medium in the proximal $(A)$ and distal $(B)$ small intestine of control (- - ) and intraperitoneal EGF-treated $(--\infty)$ animals. The results shown represent the difference between D-glucose uptake in the presence and absence of sodium. Each data point represents the mean \pm SEM of eight separate membrane preparations from both groups.

EGF significantly increased absorption rates for $\mathrm{H}_{2} \mathrm{O}, \mathrm{Na}^{+}$, and glucose. However, the increases observed in EGF-treated animals appeared to be due to two different responses that could be separated by examining transport data normalized to either intestinal length or mucosal DNA. In general, increased transport rates per unit length of intestine may be due to an increase in the number of absorptive cells or to increased transport per cell. These two effects can be differentiated by examining transport based on mucosal DNA as an index of mucosal cell number. Oral administration of EGF induced mucosal hyperplasia and increased rates of absorption per $\mathrm{cm}$ of intestine. However, when expressed per mg of DNA, rates of absorption, in general, were no different than in control animals. This would imply that the major effect of oral EGF was to increase absorptive cell number.
This was not the case for systemic EGF. Not only did systemic EGF result in mucosal hyperplasia and increased rates of nutrient absorption, but these absorption rates were still significantly increased when expressed per mg of mucosal DNA. This suggests that systemic EGF induces mucosal hyperplasia as well as increased rates of nutrient transport per cell. The increased fluidity in both proximal and distal regions of EGF-treated animals may contribute to the increased transport in vivo due to an increased cellular permeability and corresponding passive component. Additionally, because the activity of $\mathrm{Na}, \mathrm{K}$-ATPase per unit DNA was also increased after EGF administration, a case could be made for increased sodium extrusion across the basolateral membrane and a secondary enhancement of $\mathrm{Na}^{+}$-dependent absorption rates. This does not appear to be the entire explanation, however, at least in the ileum, inasmuch as studies specifically localized to the apical membrane demonstrated increased rates of glucose transport. The glucose kinetic studies demonstrated a significant increase in maximal $\mathrm{Na}^{+}$-dependent glucose transport rates, $\mathbf{J}_{\max }$, in BBMV isolated from ileum of EGF-treated animals. The passive component was also increased, but did not reach levels of significance.

The mechanism by which EGF increased glucose transport rates in ileal BBMV is unclear. Controversy exists as to the existence of a second glucose transporter protein in the small intestine similar to that observed in renal brush border membranes (51). A number of investigators have argued for the presence of two distinct transporters based on kinetic evidence (52-57), whereas others have claimed that differences in $\mathrm{Km}$ can be explained by either differences in membrane fluidity (30) or changes in cis- $\mathrm{Na}^{+}$concentration and resultant conformational changes in the transporter (58). In the present study, no firm conclusions could be drawn concerning this matter. Because our data could be equally well described by a model containing either one or two transporters, we chose the conservative approach and used a single transporter model. This, of course, does not exclude the possibility of a second transporter protein. Furthermore, many investigators describe a low affinity transporter with a $\mathrm{Km}$ in the range of 4-12 mM. Inasmuch as the upper concentration of glucose used in this study was $8 \mathrm{mM}$, we cannot reliably evaluate the presence or absence of such a transporter. Therefore, we only conclude that in the ileum systemic EGF increases the apparent $\mathbf{J}_{\max }$ for glucose transport across the apical membrane of the enterocyte. Thus, the increase in net glucose absorption observed in vivo is at least partially explained by an effect of EGF localized to the microvillus membrane.

In the suckling period, active $\mathrm{Na}^{+}$-dependent ileal transport of bile salts is deficient (59). The majority of bile salts are returned to the enterohepatic circulation via passive absorption in the jejunum. The appearance of ileal active transport coincides with weaning in the rabbit (21). We have previously demonstrated that chronic administration of EGF increases both bile salt pool size and hepatic excretion of bile salts (60). The present study demonstrates that EGF is capable of increasing taurocholate absorption and $\mathrm{Na}^{+}$-coupled transport. This increased intestinal absorption might contribute to the increased bile salt pool size previously observed (60).

In summary, EGF is able to enhance nutrient transport capac-

Table 2. Static component of microvillus membrane fluidity*

\begin{tabular}{ccccc}
\hline Group & Treatment & $\begin{array}{c}\text { Steady state } \\
\text { anisotropy }\left(\mathrm{r}_{\mathrm{s}}\right)\end{array}$ & $\begin{array}{c}\text { Limiting hindered } \\
\text { anisotropy }\left(\mathrm{r}_{\kappa}\right)\end{array}$ & $\begin{array}{c}\text { Order paramcter } \\
\left.\left(\mathrm{s}_{1}\right) \mathrm{pH}\right)\end{array}$ \\
\hline Proximal & Control & $0.266 \pm 0.002$ & $0.255 \pm 0.003$ & $0.839 \pm 0.005$ \\
& EGF i.p. & $0.259 \pm 0.003 \dagger$ & $0.245 \pm 0.003 \dagger$ & $0.823 \pm 0.004 \dagger$ \\
Distal & Control & $0.271 \pm 0.001$ & $0.261 \pm 0.002$ & $0.849 \pm 0.003$ \\
& EGF i.p. & $0.248 \pm 0.004 \dagger$ & $0.231 \pm 0.004 \dagger$ & $0.799 \pm 0.006 \dagger$ \\
\hline
\end{tabular}

* The static component of membrane fluidity was measured with DPH. Values are means \pm SEM from eight to 12 separate vesicle preparations in each group. i.p., intraperitoneally.

$\dagger p<0.01$ compared with controls. 
Table 3. Membrane phospholipid and cholesterol content*

\begin{tabular}{|c|c|c|c|c|}
\hline \multirow[b]{2}{*}{ Parameter } & \multicolumn{2}{|c|}{ Jejunum } & \multicolumn{2}{|c|}{ Ileum } \\
\hline & Control & EGF i.p. & Control & EGF i.p. \\
\hline Cholesterol (nmol/mg protein) & $262 \pm 12$ & $203 \pm 13 \dagger$ & $273 \pm 22$ & $216 \pm 16 \dagger$ \\
\hline Phospholipid (nmol/mg protein) & $233 \pm 8$ & $267 \pm 22$ & $235 \pm 11$ & $246 \pm 20$ \\
\hline Cholesterol:phospholipid (mol:mol) & $1.12 \pm 0.04$ & $0.78 \pm 0.08 \dagger$ & $1.17 \pm 0.08$ & $0.86 \pm 0.04$ \\
\hline \multicolumn{5}{|l|}{ Phospholipid subclasses (wt \%) } \\
\hline Phosphatidylinositol & $11.6 \pm 1.9$ & $13.0 \pm 1.7$ & $16.2 \pm 1.7$ & $15.2 \pm 1.7$ \\
\hline Phosphatidylserine & $8.9 \pm 1.7$ & $11.0 \pm 1.9$ & $12.1 \pm 1.7$ & $10.6 \pm 1.7$ \\
\hline Sphingomyelin (SPH) & $16.8 \pm 0.5$ & $20.0 \pm 2.4$ & $18.5 \pm 2.0$ & $17.2 \pm 1.0$ \\
\hline Phosphatidylcholine (PC) & $37.6 \pm 3.0$ & $36.0 \pm 2.0$ & $32.3 \pm 2.0$ & $45.0 \pm 2.5 \dagger$ \\
\hline Phosphatidylethanolamine (PE) & $25.2 \pm 2.0$ & $19.9 \pm 1.6$ & $20.8 \pm 2.6$ & $15.4 \pm 2.8$ \\
\hline Lysophosphatidylcholine & $<1$ & $<1$ & $<1$ & $<1$ \\
\hline \multicolumn{5}{|l|}{ Ratios (wt:wt) } \\
\hline $\mathrm{PE} / \mathrm{PC}$ & $0.67 \pm 0.11$ & $0.53 \pm 0.11$ & $0.64 \pm 0.13$ & $0.34 \pm 0.0$ \\
\hline $\mathrm{SPH} / \mathrm{PC}$ & $0.45 \pm 0.05$ & $0.56 \pm 0.12$ & $0.57 \pm 0.03$ & $0.37 \pm 0.0$ \\
\hline
\end{tabular}

$*$ Values are means \pm SEM of four determinations in each of six membrane isolations.

$\dagger p<0.01$ compared to control values in each segment.

A PROXIMAL INTESTINE
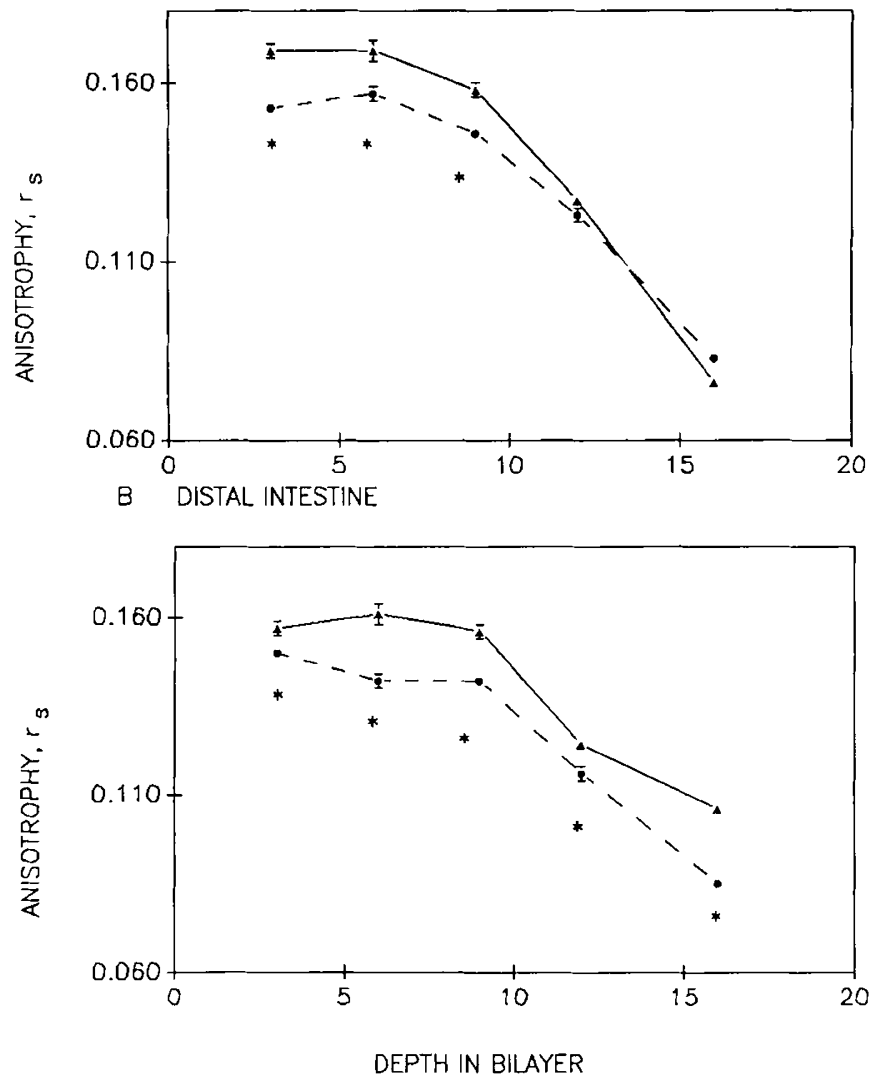

Fig. 8. Dynamic component of membrane fluidity as a function of depth in the bilayer in the proximal $(A)$ and distal $(B)$ regions. The horizontal axis represents the different probes of the $n$-(9-anthroyloxy)stearic or palmitic acid series. The vertical axis shows the fluorescence anisotropy, $r$ values. Each data point represents the mean \pm SEM of six membrane preparations from both control (—) and intraperitoneal EGF-treated (- - ) animals. ${ }^{*}, p<0.01$ compared with controls.

ity of the small intestine during the postnatal period both by increasing epithelial cell mass and inducing cellular transport processes. Furthermore, EGF has profound effects on the composition and physical properties of the microvillus membrane of the enterocyte.

REFERENCES

1. Savage RC. Cohen S 1972 Epidermal growth factor and a new derivative. Rapid isolation procedures and biological and chemical characterizations. $J$ Biol Chem 247:7609-761!
2. Cohen S 1962 Isolation of a mouse submaxillary gland protein accelerating incisor eruption and eyelid opening in the newborn animal. J Biol $\mathrm{Chcm}$ 237:1555-1562

3. Skov Olsen P. Nexo E 1983 Quantitation of epidermal growth factor in the rat. Identification and partial characterization of duodenal EGF. Scand J Gastroentcrol 18:771-776

4. Olson PS, Kirkegaard P. Poulsen SS, Nexo E 1984 Adrencrgic effects on exocrine secretion of rat submandibular epidermal growth factor. Gut $25: 1234-1240$

5. Gregory H, Holmes JE. Willshire IR 1977 Urogastrone levels in the urine of normal adult humans. J Clin Endocrinol Mctab 45:668-672

6. Barka T, Van der Noen H, Gresik EW. Kerenji T 1978 Immunoreactive epidermal growth factor in human amniotic fluid. Mt Sinai $J$ Med (NY) 45:679-684

7. Poulsen SS. Nexo E. Skov Olsen P. Hess J. Kirkegaard P 1986 Immunohistochemical locatization of epidermal growth factor in rat and man. Histochemistry 85:389-394

8. Beardmore J, Richards RC 1983 Concentrations of epidermal growth factor in mouse milk throughout lactation. J Endocrinol 96:287-292

9. Draghi E, Armato U, Andreis P. Mengato L 1980 The stimulation by epidermal growth factor (urogastrone) of the growth of neonatal rat hepatocytes in primary tissuc culture and its modulation by serum and associated pancreatic hormoncs. J Cell Physiol 103:129-147

10. Marti U. Burwen SJ, Jones AL 1989 Biological effects of epidermal growth factor, with emphasis on the gastrointestinal tract and liver: an update. Hepatology 9:126-138

11. Menard D. Arsenault P. Pothicr P 1988 Biological effects of epidermal growth factor in human fetal jejunum. Gastroenterology 94:656-663

12. Carpenter G 1979 Epidermal growth factor. Annu Rev Biochem 48:193-216

13. Gallo-Payet N. Pothier P. Hugon JS 1987 Ontogeny of EGF receptors during postnatal development of mouse small intestine. J Pediat Gastroenterol Nutr $6: 114-120$

14. Berseth CL 1987 Enhancement of intestinal growth in neonatal rats by cpidermal grow1h factor in milk. Am J Physiol 253:G662-G665

15. Malo C. Menard D 1982 Influence of epidermal growth factor on the development of suckling mouse intestinal mucosa. Gastrocnterology 83:28-35

16. O'Loughlin EV. Chung M. Hollenberg M. Hayden J. Zahavi I. Gall DG 1985 Effect of cpidermal growth factor on ontogeny of the gastrointestinal tract. Am J Physiol 249:G674-G678

17. Oka Y Ghishan FK. Green HL, Orth DN 1983 Effect of mouse epidermal growth factor/urogastrone on the functional maturation of rat intestine. Endocrinology 112:940-944

18. Younoszai MK 1981 Development of water and electrolyte transport in the small intestine. In: Lebenthal $E$ (ed) Textbook of Gastroenterology and Nutrition in Infancy, Raven Press. New York, pp 615-622

19. Shepherd RW. Hamilton JR. Gail DG 1980 The postnatal development of sodium transport in the proximal small intestine of the rabbit. Pediatr Res $14: 250-253$

20. Heubi JE. Fondacaro J 1982 Postnatal development of intestinal bile salt transport in the guinea pig. Am J Physiol 243:G189-G194

21. Buddington RK. Diamond JM 1989 Ontogenic development of intestinal nutrient transporters. Annu Rev Physiol 51:601-609

22. Perdue MH. Chung M. Gall DG 1984 Effect of intestinal anaphylaxis on gut function in the rat. Gastroenterology 86:391-397

23. Hinegardner R 1971 An improved fluorometric assay for DNA. Anal Biochem 39:197-201

24. Lowry OH, Rosebrough NJ, Farr AL. Randall RJ 1951 Protein measurement with the Folin phenol reagent. J Biol Chem 193:265-275

25. Kelly M, Butler DG, Hamilton JR 1972 Transmissible gastroenteritis in piglets: a model of infantile viral diarrhea. J Pediatr 80:925-931

26. Younoszai MK. Shapiro RS. Laughlin M 1978 Maturation of jejunum and 
ilcum in rats. Water and electrolyte transport during in vive perfusion of hyperionic solutions. J Clin Invest 62:271-280

27. Barnard JA. Ghishan FK 1986 Methylprednisolone accelerates the ontogeny of sodium-taurocholate cotransport in rat ileal brush border membranes. J Lab Clin Med 108:549-555

28. Dahlquist A 1964 Method for assay of intestinal disaccharidases. Anal Biochem $7: 18-25$

29. Hopfer U. Nelson K. Pennotto J, Isselbacher KJ 1973 Glucose transport in isolated brush border membranes from rat small intestine. J Biol Chem 248:25-32

30. Meddings JB, DeSouza D, Goel M. Theisen S 1990 Glucose transport and microvillus membrane physical properties along the crypt-villus axis of the rabbit. J Clin Invest 85:1099-1107

31. Meddings JB, Scott RB. Fick GH 1989 Analysis and comparison of sigmoidal curves: application to dose-response data. Am J Physiol 257:G982-G989

32. Meedings JB. Theisen S 1989 Development of rat jejunum: lipid permeability. physical properties, and chemical composition. Am J Physiol 256:G931G940

33. Folch J, Lees M, Sloane GH 1957 A simple method for isolation and purification of total lipids from animal tissues. J Biol Chem 226:497--509

34. Ames BN, Dubin DT 1960 The role of polyamines in the neutralization of bacteriophage deoxyribonucleic acid. J Biol Chem 253:769-775

35. Brasitus TA, Dudeja PK. Bolt M. Sitrin M, Baum C 1989 Dietary triacylglycerol modulates sodium-dependent D-glucose transport, fluidity, and fatty acid composition of rat small intestinal brush-border membrane. Biochim Biophys Acta 979:177-186

36. Goodlad RA, Wilson TJG, Lenton W, Gregory H, McCullagh KG. Wright NA 1987 Intravenous but not intragastric urogastronc-EGF is trophic to the intestine of parenterally fed rats. Gut 28:573-582

37. Scliwartz MZ, Storozuk RB 1988 Influence of epidermal growth factor on intestinal function in the rat: comparison of systemic infusion versus luminal perfusion. Am J Surg 155:18-22

38. Schaudies RP, Grimes J, Davis D, Rao RK, Koldovsky O 1989 Epidermal growth factor in the gastrointestinal tract of rats: effect of age and fasting/ feeding. Am J Physiol 256:G856-G86

39. Thompson JF 1988 Specific receptors for epidermal growth factor in rat intestinal microvillus membranes. Am J Physiol 254:G429-G435

40. Scheving LA, Shiurba RA. Nguyen TD, Gray GM 1989 Epidermal growth factor receptor of the intestinal enterocyte. Localization to laterobasal but not brush border membrane. J Biol Chem 264:1735-1741

41. Johnson LR. Tseng C. Wang P, Tipnis U, Haddox M 1989 Mucosal ornithine decarboxylase in the small intestine: localization and stimulation. Am $J$ Physiol 256:G624-G630

42. Ulshen MH. Lyn-Cook LE, Raasch RH 1986 Effects of intraluminal epidermal growth factor on mucosal proliferation in the small intestine of adult rats. Gastroenterology 91:1134-1140

43. Schwarz SM, Hostetler B, Ling S, Mone M, Watkins JB 1985 Intestinal membrane lipid composition and fluidity during development in the rat. Am J Physiol 248:G200-G207
44. Schwarz SM, Bostwick H. Danziger MD, Newman LJ, Medow MS 1989 Ontogeny of basolateral membrane lipid composition and fluidity in small intestine. Am J Physiol 257:G138-G144

45. Hirata F, Axcirod J 1980 Phospholipid methylation and biological signal transmission. Science 209:1082-1090

46. Iwatsubo T, Yamazaki M Sugiyama Y Suzuki H, Yanai S, Kim D, Satoh H, Miyamoto Y, Iga T, Hanano M 1989 Epidermal growth factor, as a regulatory hormone maintaining a low-pH microclimate in the rat small intestine. J Pharm Sci 78:457-459

47. Shinitzky M 1984 Membrane fluidity and cellular functions. In: Shinitzky M (ed) Physiology of Membrane Fluidity. CRC Press, Boca Raton, FL, pp 1 53

48. Schwarz SM, Bostwick HE, Medow MS 1988 Estrogen modulates ileal basolateral membrane lipid dynamics and $\mathrm{Na}^{+}-\mathrm{K}^{+}$ATPase activity. Am J Physio 254:G687-G694

49. Brasitus TA, Dudcja PK, Worman HJ, Foster ES 1984 The lipid fluidity of rat colonic brush border membrane vesicles modulates $\mathrm{Na}^{+}-\mathrm{H}^{+}$exchange and osmotic water permeability. Biochim Biophys Acta 774:138-146

50. Brasitus T. Schacter D 1982 Cholesterol biosynthesis and modulation of membrane cholesterol and lipid dynamics in rat intestinal microvillus membranes. Biochemistry 21:2241-2246

51. Hediger MA, Turk E, Pajor AM, Mohandras TK, Wright EM 1989 The human renal sodium/glucose cotransporters. FASEB J 3:1951

52. Brot-Laroche E, Serrano MA. Delhomme B, Alvarada F 1986 Temperature sensitivity and substrate specificity of two distinct sodium activated D-glucose transport systems in guinea pig jejunal brush border membrane vesicles. J Biol Chem 261:6168-6176

53. Freeman HJ, Quamme GA 1986 Age related changes in sodium-dependent glucose transport in rat small intestine. Am J Physiol 251:G208-G217

54. Harig JM. Barry JA, Rajendran VM, Soergel KH, Ramaswamy K 1989 Dglucose and L-leucine transport by human intestinal brush-border membrane vesicles. Am J Physiol 256:G618-G623

55. Kaunitz JD, Wright EM 1984 Kinetics of sodium D-glucose cotransport in bovine intestinal brush border vesicles. J Membr Biol 79:4I-5I

56. Kwan WC. Quamme GA. Freeman HJ 1987 Sodium-dependent D-glucose transport in brush-border membrane vesicles after massive distal small bowel resection in the rat. Gastroenterology 92:1987-1993

57. Malo C 1988 Kinetic evidence for heterogeneity in sodium D-glucose cotransport systems in the normal human fetal small intestine. Biochem Biophys Acta 938:18!-188

58. Peerce BE. Wright EM 1984 Sodium induced conformational changes in the glucose transporter of intestinal brush borders. J Biol Chem 259:1410514112

59. De Belle RC, Vauphas V, Vitullo BB, Haber LR, Shaffer E, Mackie GG, Owen H. Little JM, Lester R 1979 Intestinal absorption of bile salts: immature development in the neonate. J Pediatr Res 94:472-476

60. Opleta K, O'Loughlin EV, Shaffer EA. Hayden J, Hollenberg M, Gall DG 1987 Effect of epidermal growth factor on growth and postnatal developmen of the rabbit liver. Am J Physiol 253:G622-G626 